\title{
A Structuralist Study of Chinua Achebe's Anthills of the Savannah
}

\author{
Ononiwu, Mark Chitulu (Corresponding author) \\ Federal University of Technology, Owerri, Imo State, Nigeria \\ E-mail: mctv_ono@yahoo.com \\ Njemanze Queen \\ Federal University of Technology Owerri Imo State, Nigeria
}

Doi:10.7575/aiac.alls.v.6n.3p.93

Received: 18/01/2014

URL: http://dx.doi.org/10.7575/aiac.alls.v.6n.3p.93

Accepted: 25/03/2015

\begin{abstract}
Major African writers have never stopped exploring the themes of corruption, radical struggles and political instability in their respective domains. One of these writers and his monumental classic, Chinua Achebe; Anthills of the Savanna, discusses these themes expertly and with utmost dexterity. The major task of this paper is not to discuss the themes, rather to study the underlying structures of signification as they are applied in the structure of the narrative. The researcher therefore, will attempt to identify the smallest meaningful units in the text and study their modes of combination with the sole aim of comprehending fully how the meaning and thematic content of this narrative is created instead of interpreting the actual meaning conveyed. Simply put, this study will take a deep incursion into the methods through which the author deftly gets these themes across to his audience.
\end{abstract}

Key words: structuralism, semiotics, narrative, Actants, functions, binary oppositions

\section{Introduction}

The structural analysis of narrative dates back to the 1920s with the works of scholars like Vladmir Propp's Morphology of the Folk-Tale (1928). This work appeared in French translation in 1957 and in English in 1968. In this work, he noted that though the individual characters in Russian tales were very diverse, their functions could be described in a limited number of terms. He suggested thirty one functions which fell into seven super-ordinate categories. By reference to these elements therefore, "the narrative ordering of any tale could be analyzed as a sequence of functions of its dramatic personae and associated actions". This, the researcher believes is a generative grammar of narrative: a finite system (paradigm) of abstract units generating an infinite set of narrative sequence (Syntagms). Another scholar, A.J. Greimas picked up Propp's analysis and gave it a sophisticated reinterpretation in semantic terms. He did this in his book Semantic Structurale (1966). It thus became a standard assumption in narratology that the structure of a story was homologous with the structure of a sentence. This assumption allowed the apparatus of sentence linguistics to be applied to the development of metalanguage for describing narrative structure. The works of Roland Barthes, Tavetan Todorov and Gerrard Genette are particularly important to this development.

At this point, it is important for the researcher to bring into focus, the primary aim of this research work which is to make an in-depth study and analysis of the narrative structure of Chinua Achebe's Anthills of the Savannah. In other words, the novel, will be subjected to the analysis of narrative structure, as already stated above, in an attempt to explain and understand, how it is that literary works like Anthills do have meaning for us.

\section{Basic Concepts}

\subsection{Structure}

Roger Fowler sees structure as a term "all critical theories have some notion of. His belief about structure is that "every work is a distinct and verbally created universe and must have a self-created logic or sequence for which the author is responsible" (Fowler, 1987 p.234).

The work must possess its own expectations and probabilities which constitute the unity of the universe. There is likely to be a coherence of social relationships such as, a coherence of action constituting a plot, coherence of attitude constituting a tone; coherence of rhetorical fact, or point of perception and view, constituting a technique or (in a local sense) a language. There are likely to be other significant blocks of coherence - metrical and stanzaic features, acts and scenes and generic conventions. As we start reading a work, we recognize that an author, starting writing has made certain committing choices, where to begin his action, from which standpoint to see it, and which language and convention to maintain. As we continue reading, "we discover that from these, a logic flows - not a single logic of tone, technique, story or metaphor, but a system of development or order which enables us to structure our own perceptions, acquire a sense of relevance, and see what is persistent and significant in this universe" (Fowler, 1987 p.234). 


\subsection{Structuralism}

Structuralism is a term which "studies the structures or systems of relations by which cultural objects are defined and distinguished from one another".

It is an intellectual discipline which gradually developed momentum during the $20^{\text {th }}$ century, influenced by formalism and the Prague school. This field of study Is particularly associated with a group of French Scholars writing after the second world war. It got to its peak around the 1960s with scholars like Claude Levi-Strauss, Roland Barthes and Michel Foucault as its exponents.

The basic premise of structuralism is that human activity and its products, even perception and thought itself, are constructed and not natural. Thus, a structure like the conventional sequencing of episodes in fairy stories or narratives is not merely "an insignificant mechanical ordering" (Culler 1977, p.61). Each element in the structure, be it "unit" or "transformation has meaning in the Saussurean sense of value, because it has been selected from a system of options and is therefore defined against the background of other possibilities.

This term or concept is greatly indebted for a model to the ideas of Saussure. Structuralists follow Saussure in emphasizing the arbitrariness of the relation between signifier or form and the signified or concept, and in stressing the importance of difference between signs.

When it is applied to literature, Structuralist ideas give rise to an analytical approach that is more theoretical and broader than other approaches and is best viewed as a (Structuralist) poetics. Here, interest centres not so much on the evaluation of individual texts, as in literary criticism, but on their structural patterns, as can be seen in the works of Roman Jakobson on selected poems. Very strong interest is also laid on interpretative codes and the formal properties and conventions of texts within a genre.

Of extreme importance to structuralist criticism is the readers activity of reading which bring into play requisite conventions and codes that lend significance to the sequence of words encountered by the reader. In other words, the system that underlies readers interpretative acts is of paramount importance, if the structuralist critic must discover how meaning is conveyed in a literary work. (Robey, 1983).

\subsection{Types of Structuralism}

There are two basic types of structuralism. The first one concerns the patterns which are formed by linguistic elements in a work and the examination of these patterns to find which ones unify the text and throw certain elements in relief.

The second and more common type, one with very close affinities to semiotics, sees, literary conventions and forms as constituting "a system of codes that contribute to and convey meaning" (Wales 1984 p.434). The special interest here is on the organization and function of distinctively literary elements, on how meaning is conveyed rather than what meaning is conveyed. On how a literary device or even genre functions rather than how it imitates an external reality or expresses an internal feeling.

\subsubsection{Semiotics}

"Semiotics is the branch of linguistics that deals with the study of signs: their production and communication, their systematic grouping in languages or codes and their social functions. It is doubly relevant to the study of literature, for literature uses language, the primary system in human culture, and is further organized through various subsidiary codes, such as generic conventions.

Roger Fowler in his extensive work on semiotics, argues with Saussure that "Language is a system of signs that expresses ideas, and the interrelationship of these signs determine meaning". He goes on to state that "the expressive function of the sign is achieved through its components of signifier (as image or form) and signified (as concept or idea); their linkage with our minor exceptions, is seen as arbitrary and unmotivated" (Fowler, 1987, p232).

\subsubsection{Functions and Indices}

In a structuralist criticism, our interests lie in establishing codes for linguistic descriptions. The most fundamental of these structuralist codes are functions and indices. Ann Jefferson discusses Roland Barthes reference to them as "basic units of narrative". According to her, "these basic units of narrative are defined and differentiated principally in terms of their narrative effect and not of any prior linguistic analogies that he may have found for them" (Jefferson 1986). Barthe's distinction between function and index (two of his basic narrative units) is determined by whether the units link with others to form a chain of actions( the functions), or whether their role is a more diffuse contribution to the meaning of the story, such as information about characters (the indices). The functions, Barthe suggests, are based on metonymic relations, the indices on metaphoric relations. Thus, from the above, we can understand that functions are units that correlate with other units in a narrative and all these units will come together to form a structure that has a horizontal movement. While indices deal with characters in the text. They are culturally bound. In order words, their interpretation is based on the cultural milieu of what is being discussed in the text.

\subsection{Binary Opposition}

The concept of binary opposition is fundamental to much structuralist theory. One phoneme, the lowest level of linguistic unit, is distinguished from another by its difference. The difference between the two sibilants $/ \int /$ and $/ \mathrm{s} /$ is expressed in terms of a binary opposition - 'voiced' and 'unvoiced'. All sign systems are similarly identified in terms by binary patterns (on- off, presence - absence, sweet, sour, cooked - raw, e.t.c.). 
Literary systems too can be expressed in terms of binary oppositions. Claude Levi Strauss, the French Anthropologist is the master exponent of this type of structural analysis.

The types of binary oppositions which have been found very useful in structuralist criticism are Mimesis/Diegesis, Metaphor/Metonying, Narrative/Discourse. One particular binary opposition - metaphor/Metonymy has proved especially fruitful as a heuristic device in literary criticism. (Levi Strauss 1995).

\subsubsection{Genetic-Transformational Microstructure}

Fernando Ferrar summarizes the structural study of the work fiction as "the study of the genetic transformational microstructure called character, developed in relation to the corresponding macrostructure which accounts for its genesis and functions" (Terara, 1994).

From this, it is clear that Ferrara sees character as the structuring element in fiction. He even sees or defines fiction as "communication through characters". (Ferara 1994) By characters, Fernando Ferrar means "a partial or total stylized, rationalized, and interpreted reconstruction of a human being capable of fulfilling itself in a story". It is this same character that A.J. Gremais calls actants in his structural Semantics.

\subsection{Functions, Indices, and Binary Opposition as Structuring Codes in Anthills of the Savannah}

\subsubsection{Functions and Indices as Structuring codes in Anthills}

Functions are units of narrative which link up linguistically into structures. In this chapter, we shall examine some units of narrative with the aim of discovering how they contribute to and convey meaning in Anthills.

“You are wasting everybody's time, Mr commissioner for Information. I will not go to Abazon.

Finish! Kabisa!... but me not buts, Mr Oriko! The matter is closed, I said.” (Anthills p.1).

Looking at this statement made by the president at the beginning of the novel, we will notice two things. First, he talks to members of his cabinet rudely even when they make useful suggestions about state of matters. Secondly, he does not want to see Abazon's at all. When therefore we see him in page 17 giving professor Okong, one of his ministers, instructions on how to deal with the delegation that came to visit him from Abazoon, we are not surprised.

"Well you know - everybody knows - my attitude towards petitions and demonstrations and those kind of things, I have a standing order to all of them, No Kabisa." (p.16).

He then goes on to tell Professor Okon;

"Tell them if you like that I am on the telephone with the President of the United states of America and the queen of England."

For the president of a country to say no to any delegation without considering their requests, be it reasonable or unreasonable is outrageous. Then, for him to advise his minister to tell them a lie believing that it will interest them is incredible. When therefore, he accuses Ikem of "conspiring with thugs to invade the presidential palace" (p.144), and also colluding "with the same people to sabotage the presidency referendum, two years ago" (p.144) we realize why he has flatly refused to see the people of Abazon.

The way these units of narrative correlate from pages 1 to 144 shows how despicable and heartless this ruler is to his own people. Within the cultural milieu(indices) of our text Anthills, we shall see that the quotations from pages 1 and 17 portray the president as a wicked ruler indifferent to the sufferings of his people.

\section{"Days are good or bad for us now according to how his Excellency gets out of bed in the morning” (p. 2).}

If the days are good or bad for members of his cabinet depending on the mood he is in when he wakes up in the morning, we shall not be surprised when he warns and reminds his cabinet that he is still a soldier.

"You all seem to forget that I am still a soldier and not a politician" (p.4). .

When we then see in the novel that there were unconfirmed rumours of unrest, secret trials and executions in the barracks. But his Excellency rode the storm quite comfortably, thanks to two key appointments he had personally made - the army Chief of Staff and the Director of the State Research Council, the secret police. We now understand his former reference to the fact he was still a soldier. The way these units of narrative link show us that the president is simply a military despot. A dictator of the highest order. Within the cultural milieu of the text, Anthills, his Excellency cuts the image of a power monger who wishes to stay in power all his life.

At this stage, we shall consider the basic units of narrative as they concern Chris Oriko with a view to showing how they contribute to and convey meaning in the text.

"I am sorry your Excellency, I have no difficulty digesting and swallowing your rulings"(p.1).

Chris Oriko falls into trouble with the president just for defending and protecting the interest of the Abazonians. Neglecting the demands of the Abazonians is equal to sheer injustice and evil, so Chris, tries to bring this to the notice of the president and gets into trouble. Other troubles, he gets himself into, and even the one that leads to his death were caused by his trying to speak up against evil and demand for justice. The following units of narrative which correlate show how Chris died because of his constant crusade for justice and fairplay in the text. 
"Your Excellency, I wish to dissociate myself from the Attorney General's reference to a saboteur and to appeal to my colleagues not to make such statements against public servants who are not present to defend themselves".

Ikem Osidi is the person who is being referred to as a saboteur by a minister and Chris goes on to defend him. This defense correlates with the one done for Abazoonians and also with this one

"I am sorry, your Excellency but I will not write a letter suspending the editor of the National

Gazette simply because some zealous security official has come up with a story "(p.144).

This unit of narrative shows us how vicious the president is. He want's Ikem sacked because he suspects him of conspiracy with the Abazonians which is not true. Though he finally sacks Ikem, Chris is not a party to it.

For a president to sack an editor because of unfounded rumours shows how backward he and his policies must be.

Looking at these three units of narrative from the cultural milieu of the novel we see the president as a perpetrator of evil and injustice and Chris as a crusader of justice and fairplay. The final unit of narrative we shall consider correlates with the rest and it sounds the tragic note and structure of the novel and of Chris.

"Chris bounded forward and held the man's hand and ordered him to release the girl at once. As if that was not enough, he said, I will report you to the inspector General of Police.

Chris' constant battle with the forces of injustice and evil in his society finally robs him of his life. Within the cultural milieu of the text, Chris' death denotes the demise of the force of justice and fairplay in Africa. He is the lone voice in the wilderness of the Anthills crying for justice, unfortunately, the forces of injustice got rid of him.

The correlation of these various functions and indices about Chris and the president contribute to and convey the meaning of the novel Anthills to the readers.

The units of narrative which reveal the wicked and despicable nature of Sam as a president and the futility of Chris' constant crusade against injustice contribute to and convey the meaning of "disenchantment" with political leadership in Africa. It is worthy to note in this research work that, our focus is not on the meaning of Anthills but how this meaning is conveyed to the reader. Thus, with the "functions" of these two leaders in the text, we have been able to see how the meaning of political disenchantment is conveyed in the novel.

\subsubsection{Binary Oppositions as Structuring Modes in Anthills of the Savanna}

Structuralists find the concept of binary opposition very useful in their analysis. The reason for this is that, to a great extent, it contributes to meaning (Hugh \& Herman 1986).

In Achebe's Anthills of the savannah, we are going to look at eight different levels of binary oppositions. Specifically, the opposition between the rich elite and the poor illiterates. The second is the opposition in the point of view while the third is that between diegesis and mimesis or narrative and discourse. The fourth binary opposition is that between the president and his cabinet, the fifth between Chris and the cabinet, the sixth between Chris and Ikem, the seventh between the Director of the state Research council (SRC) and the President's cabinet and finally, the opposition seen in the president's ambivalent nature. Because of the nature of this research, it will not be possible to discuss the whole binary oppositions stated. However, a significant number of them, which are of prime importance to the theme of this research shall be discussed.

The first to be discussed is the actantial opposition. This opposition deals with the way the actants appear in the novel; they are divided into two different categories. The intellectual and rich people and the poor illiterates. The president, his cabinet, BB and the Mad medic belong to the group of rich intellectuals, while Elewa, Agatha, the market women, Taxi drivers and trade unionists are some of the poor illiterates(masses).

In the interaction of the two groups, there is a striking difference. When the delegation from Abazoon came, the president refused to see them and sent his minister for home affairs. The way the cabinet treated the Abazon case leaves much to be desired. Wherever the rich and the poor are juxtaposed in the novel, there is a difference. BB and Agatha live together but are two different people. There seem to be a point of convergence whereby, Chris, the taxi drivers and the trade unionists come together. In spite of this, there is a very clear difference between them and Chris.

The type of relationship one deduces from this opposition is that of the ruler and the ruled, the oppressor and the oppressed. Thus, we see this particular binary opposition contributing immensely to the meaning of the novel which can be said to be a form of disenchantment with military rule and politics in Africa.

Another binary opposition is the opposition between the president and his cabinet members. The ideal relationship between them should be, seeing the president as a first among equals and not as a demi-god. Unfortunately, they see him as demi-god. He treats them with ignominy and has very little regard for them.

"Good day, your Excellency, Mr President", intoned professor Okon executing at the same time a ninety degree bow. No reply, nor any kind of recognition of his presence. His Excellency continued writing on his drafting pad for a full minute before looking up. (p.14).

This treatment given to professor Okon is the same given to other members of the cabinet. The president sees himself as an intelligent man and the members of his cabinet as fools. So he works alone, takes decisions and makes them carry these decisions out. This is an unhealthy practice for a president and it is not favorable to political leadership. 
The opposition between Chris and other members of the cabinet is very glaring. While Chris is straight forward and honest, others are sycophants, gossips, and praise singers. A good example is professor Okong's utterances about Chris in the president's office

"well your Excellency, I am sorry to be personal... I believe that if care is not taken, those two friends of yours can be capable of fermenting disaffection which will make rebellion look like Child's play." (p.20).

The rebellion reffered to is the supposed Abazonians rebellion which Chris knows nothing about. The president's reply is

“That's fine, Mr Okong. I deal with facts not gossip" (p.20).

For a cabinet member of a government to indulge in gossips against his colleagues is terrible and counter productive to positive leadership. Another cabinet member, the attorney-general, tells his Excellency, "I don't think Chris is one hundred percent behind you". (p.23).

He continues,

"My impression is that he does not show any joy, any enthusiasm in matters concerning this government in general and your Excellency in particular". (p.23).

This type of opposition between Chris and other members of the cabinet is a terrible power game which can never encourage good leadership in any state. Such a situation fosters retrogression.

The next opposition is that between the Director of State Research Council (SRC ) Major Johnson Ossei and the President's cabinet. This particular opposition is mentioned by the president. To him, there is an opposition between competence and incompetence here.

"He proved nice again, in his Excellency's words as efficient as the cabinet was incompetent. "

(p.14).

Major Johnson is a very callous and wicked man whom the president uses to perpetrate his wicked activities. This is the genesis of the president's love for him. Incidentally, the president cannot make use of his cabinet as he uses Major Ossei. So he sees them as incompetent. For Sam, his Excellency, to refer to the person he uses to strengthen his acts of despotic leadership as very competent and his own cabinet, as very incompetent, suggests to the reader how terrible and unworthy he is as a leader.

The binary opposition we shall finally discuss, is the president's ambivalent nature. He says one thing and does the exact opposite of whatever he says.

"Worshipping a dictator, can be a pain the arse... The real problem is having no way of knowing

from one day to another, from one minute to the next, just what is up and what is down. (p.45).

The president told Chris he would pay a visit to Abazon and Chris went and told the people about it. But within a short time, he changed his mind and according to Ikem said

"I must not go and visit my loyal subjects at Abazon" (p.15).

For a president to exhibit such a quality and character trait shows the type of leadership his people get from him.

In all, these binary oppositions contribute to and convey one particular type of meaning: that His Excellency, his cabinet and all those around him do not rule well. On a more general note, they convey the meaning that leadership in Africa is still very corrupt, crude, incompetent and bedeviled by various problems.

\subsection{Character as Structuring Element In Anthills of the Savannah}

\subsubsection{Structuralist View of Character}

The structuralists believe that character plays a significant role in the structural study of the work of fiction. It characterizes the entire work of fiction and constitutes its essential and most meaningful part. Fernando Ferrara in his article "Theory and Model for the Structural Analysis of Function", suggests that fiction could be defined as "communication through characters". (p.249)

In fiction therefore, character is used as structuring element. Consequently, the objects and various events of fiction occur because of character and "it is only in relation to it that they possess those qualities of coherence and plausibility which make them meaningful and comprehensible" (Ferrara, p.350). It is as a result of these reasons that we see the structural study of the field of fiction as a study of the structure of character.

This analysis and study of character originates from two basic postulations. That "character in a narrative fulfills the requirements of all structured systems and is in fact a genetic transformational structure; the second maintains that the structure of a character is organized at various levels and is divided into deep structure (or genetic matrix). Middle structure (or transformational zone) and surface structure (or terminal string)" (Fowler, p.216).

This surface structure is the story of a character that develops in time and space, while the middle structure is the personality for the character itself.

The deep structure is the set of values of the character. It contains the genes which control the development of characteristic traits, their reciprocal al relation, and their relations to their context. 


\subsubsection{Character as a Structuring System in Anthills of the Savannah}

In this section, the researcher is going to examine the structure of character in Anthills and how it aids in the contribution of meaning and intelligibility to the entire text.

The structure of character in Anthills of the Savannah is divided into two broad divisions. The rich intellectuals and the poor illiterates. They can also be grouped as rulers (the rich intellectuals) and the ruled (the poor illiterates). From this division, we shall have the president, his cabinet, Chris Oriko, Ikem Osodi and Beatrice as members of the rich intellectual class; the elite. The people of Abazon the market women, Agatha, Elewa, Elewa's mother, and uncle, Braimoh and his wife represent the poor illiterates in the novel.

Towards the end of the novel, there emerges a crop of new characters with whom the novel ends. They are Adanam, Emmanuel, Aina, Amnechina (Ikem's son from Elewa). Major General Ahmed Lango and Captain Medani. Each of these characters has his or her own thematic relevance to the novel.

There exists some types of association among characters in Anthills. Some characters are structurally associated to complement or contrast others so as to shed more light on the meaning of the novel as well as reinforcing the thematic content and structure of the work. Some members of the rich intellectual class are contrasted with some of those in the poor illiterate class. Also, there exists, a subtle type of structural contrast among members in the rich intellectual class.

These contrasts contribute a lot of meaning to the text. That between the president and people of Abazon shows the president's indifference to the welfare of the people he is ruling.

That between Chris and the police constable who shoots him shows the tragedy of the quest for justice and fairplay in Africa.

The contrast between Ike Osodi and Elewa is very significant. It helps to bring out the outspoken, eccentric and daring quality of Ikem. His outspoken and daring quality finally led to his death in the hands of the law enforcement agents on the orders of the president.

The constructive association between Ikem and Chris shows Ikem's lack of diplomacy in dealing with state matters. Chris says to him

"Lie low for a while and this gathering tornado may rage and pass... But oh no! Ikem is outraged that I should recommend such cowardly and totally unworthy behavior to him"(p.119).

African rulers are afraid of people like Ikem who stop at nothing in exposing their sordid ruling methods. So, naturally, the best thing to do is to eliminate him and stop his stinging editorials against the government. Chris foresees this and then tells Ikem to pedal slowly but Ikem refuses, thus his death; the death of boldness and truth among the ruling class of Kangan.

Simply put, the contrast between Ikem, Chris and BB versus the president and the rest of his cabinet is the contrast between justice, truth and fairplay on the part of Chris, Ikem and BB as against lies, petty gossips and injustice on the part of the president and his cabinet. This particular contrast shows the problems of leadership in Africa.

The reference to Ikem, He (the president) and Chris as the three green bottles is of structural importance. The incidents and actions in the novel principally revolve round these three main characters. All the actions of these three and their subsequent death send this message to us

"This world belongs to the people of the world, not to any little caucus, no matter how talented...." (p.233).

\subsection{Literary Conventions and Forms: A System of Codes that Contribute to and Convey Meaning in Anthills}

Structuralist criticism focuses on the reader's activity of reading which brings into play requisite conventions and codes that lend significance to the sequence of words in the narrative and help to convey meaning.

In this chapter, we are going to consider the requisite conventions and codes which lend significance to the sequence of words in Anthills and therefore, help the readers to interpret the meaning of the work.

The most important conventions and codes which underlie the readers' interpretative acts in Anthills are imagery, symbolism and irony.

\subsubsection{Imagery}

The occurrence of imagery in Anthills forms one of the very important systems that underlie reader's interpretative acts. "One striking feature of this novel" according to Kofi Yankson "is the prominence of bestial imagery. The patterning of behavior of all the main characters are described in terms of animal behavior" (Yakson 1990 p.137). Such bestial or animal images are the imagery of crawling creatures, the bird imagery, dog imagery, the tortoise imagery, the bug imagery and the goat imagery.

The description of the pattern of behavior of the characters in bestial imagery makes the reader to conclude that bestiality permeates every level of life in a tyrannical state like Kangan. One example of such imagery is that of crawling creatures. This is used to refer to the hypocritical disposition of the cabinet members.

Chris Oriko says of them:

"when the president happens to be in a bad mood, there is nothing left for his cabinet but to lie close to its hold ready to scramble in (p.2)" 
The animal imagery in Anthills defines the relationship between the president and his cabinet. If the former is a ruthless beatst of prey, the latter is a despicably spineless creature. A group of men who lack moral courage and self esteem.

Ikem Osodi, becomes a prey of the president. This is because he refuses to crawl before his Excellency, the way other intellectuals do in the cabinet. He writes "crusading editorials" in order to educate the people and when Chris advises him to lie low after his suspension, he replies:

"but people are going to ask questions and I shall bloody well answer. I'm not going to crawl into a hole”. (p.149).

Unlike the frightened intellectuals in the cabinet, Ikem has the intellectual and moral courage to search and speak the truth. Because of this, he is referred to as the white cockerel (another bestial imagery) by the leader off the Abazon delegation to the presidential palace.

Another recurrent animal image we shall consider is the dog imagery. The Kangan mobile police is portrayed in the image of a fierce dog.

"Teasing them is worse than challenging a hungry Alsatian" (p.173).

The dog imagery is quite appropriate for a society where the commander in chief of all the security agencies sees himself in the image of a lion. Also, Ikem Osodi is referred to as a

"running dog of imperialism”(p.157)

by the leaders of the civil service union because he called them plain parasites.

Apart from the bestial imagery, we have the image of the three green bottles. This image represents Sam, Chris and Ikem. It depicts rulers of the highest order. It can be likened to Christian trinity; the father, the son and the holy spirit. It shows that Chris, Sam and Ikem are the hghest rulers in Kangan. According to BB,

"they are the trinity who thought they owned Kangan... three green bottles" pp 191).

The green in the green bottles connotes ignorance and naivety while the bottle symbolizes the brittleness and glassy essence of man. This imagery shows the nature of the rulers who were in charge of kangan.

\subsubsection{Symbolism}

This is another important code which underlies the readers interpretative acts in Anthills.

The second-hand cloth seller in the novel is a symbol of society's helpless underdog. We recall that when the solder reverses an army car and nearly knocks him down, he ask him :" Oga you wan kill me?" and the soldier replies with contempt,

"If I kill you, I kill dog." (p.48).

The young man then becomes a dog that can be killed without any questions from the authorities. This shows the type of terrible society Kangan is. No citizen is safe even in the hands of the rulers who should protect them.

In the novel, Ikem is a symbol of hope and the fact that corruption must be exposed is opposed.

His stinging editorials in the national Gazette and his lecture at the University of Bassa entitled

"The tortoise and the leopard - a Political meditation on the imperative of struggle",

Ikem represents the tortoise who was about to die, while he, the president is the leopard. Like the tortoise, Ikem simply wants the future generations to know that tyranny and massive corruption will always be opposed. With the intellectual and moral courage to search for and tell the truth, there will be hope for the African continent.

The three green bottles are symbolic in Anthills. They symbolize the transient nature of tyrannical power in any political system. The people who represent the three green bottles all die one after the other and the death of the last two ushers in the tragic end of the novel.

The description of the president's clothing and that of the leader of the armed robbers is very symbolic and of the same time, ironic. We are told in page four that the president wears a "white danshiki tastefully embroidered in gold and its matching trousers." While the leader of the armed robbers (a prince among criminals) is so unrepentant that he also wears "a spotless white lace danshiki, embroidered with gold thread, and natty blue terylene trousers" (p.41) to his execution. The juxtaposition of these two individuals indicates that both of them are evil. They both symbolize oppression and exploitation. The white in the white danshiki connotes innocence but these two men are wolves in sheep's clothing. This is where the irony of the two princes lies.

The last symbol we shall deal with is the symbol of aloofness, extravagance, corruption, and arrogance of the entire political class of kangan. This symbol proper, is the "presidential retreat" with its

\section{"great shimmering expanse of artificial lake waters... and the brightly lit avenues" (p.73).}

This retreat we are told was built with 45 million and later refurbished with twenty million by the present administration. Of what need is this retreat? From whom? From the people and their basic needs water... shelter and food". (p.73). the president refuses to visit the people of Abazon and grant their requests for welfare. But he could afford twenty million merely to refurbish a presidential retreat. This shows how wicked, corrupt, and incompetent the government of kangan is. 


\subsubsection{Irony}

One of the structural ironies used to achieve meaning in Anthills is the irony inherent in the contrast between the president's former image of self-assured, self-proclaimed lion ensconced in the luxury and safety of his palace, and his present portrayal as a missing goat. Through the sergeant, the reader can deduce the fact that he is a "goat" - "a fool". He should have realized the risks and implications of power.

The title of the book Anthills of the Savannah is ironic. The word Anthills is associated with the ant colony which is known for its well organized and harmonious ant world. But it is ironic that this term, Anthills, refers to the extremely chaotic and disillusioned human world of the novel filled with corruption, disappointment and exploitation. These goes on to highlight the fact that the ants have a good sense of communal relationship, but men take delight in exploiting and suppressing their fellow men.

\section{Conclusion}

This structuralist study of Anthills of the Savannah, has shown clearly that many authors of African literature, particularly, those like Chinua Achebe, who are master craftsmen in the art of creative writing, will leave no stone unturned in exposing the dirty linens of corrupt and despicable African leaders.

Achebe's attempt to bring to the forecourt of the reader's attention, the theme of corruption and political lethargy and backwardness on the part of the Nigerian ruler in particular, and the African politicians in general was made possible by his use of selected narrative codes and modes which brought a lot to bear on the meaning and structure of the text, Anthills.

\section{References}

Abrams, M.H. (1999). A Glossary of Literary Terms $7^{\text {th }}$ Edition: USA: Holt.

Achebe, C. (1998). Anthills of the Savannah. Ibadan: Heinemann Educational Publishers Ltd.

Claude, L. S. (1983). Myth and Meaning; Cracking the Codes of Culture. Schoken Books New York.

Claude, L. S. (1963). Structural Anthropology: Basin Books USA.

Crystal, (1989). A First Dictionary of Linguistics and Phonetics. London: Andre Denetsch Ltd.

Culler, J. (1997). "Structuralism in Literature" in Contemporary approaches to English studies. Ed. Hilde Chiff USA: Harper and Row Publishers.

David, R. (1983). Structuralism; An Introduction. Clarendon Press, London.

Ferrara, F. (1974) "Theory and Model for the structural analysis of Fiction" in New Literary History. A Journal of Theory and Interpretation, $V(2)$.

Fowler, R. (1973). A dictionary of Modern critical terms. London: Routledge and Kegan Paul Ltd.

Homan, C. H. and William, H. (1986). Handbook of literature. New York: Macmillian.

Jefferson, A., and David, R. (1986). Modern Literary Theory: A Comparative Introduction. London: B.T. Betsford Ltd. Josiporia, G. (1977). The Lessons of Modernism and other Essays. London: Macmillan.

Katie, W. (1984). A Dictionary of Stylistics. London: Longman.

Kofi, Y. (1990). Chinua Achebe's Novels; A Sociolinguistic Perspective. Obosi, Nigeria: Pacific Publishers. 